\title{
情報の生成が語の偶発記憶に及ぼす効果
}

\author{
奈良教育大学 豊 田 弘 司
}

\section{Effect of information generation on incidental memory of words}

Hiroshi Toyota (Department of Psychology, Faculty of Education, Nara University of Education, Takabatake-cho, Nara 630)

The present study was carried out to investigate the effect of information generation on incidental memory of words. Subjects in the subject-generated group were asked to generate a converging associate of three targets in each triplet. Subjects in the experimenter-provided group were asked to rate the relation between targets and a paired-presented word on 5-point scale. Each subject in both groups were given an unexpected free recall test. Recall performance for targets in each unrelated triplet in the subject-generated group was higher than in the experimenter-provided one. Conditional probablity of recalling targets given relational information was an index of effectiveness of within-item elaboration. This index was higher in the subject-generated group. These results were interpreted as showing that the effect of information generation was caused by the effectiveness of within-item elaboration.

Key words : elaboration, generation, incidental memory, within-item elaboration.

豊田(1987) は，従来の精緻化研究を展望し，一般的 には，精緻化とは記憶項目に情報を付加することであ り，精緻化の有効性を高める情報としては，かつて Hunt ら (Hunt \& Einstein, 1981; Hunt \& Elliott, 1980) が指摘した記銘語と他の記銘語との関係に関する情報 (関係情報)及び他の記銘語との差異性に関する情報 (項目特殊情報)があり，関係情報を付加する精緻化を 項目間精緻化 (between-item elaboration)，項目特殊情 報を付加する精緻化を項目内精緻化 (within-item elaboration)と呼んでいる(豊田, 1987).

ところで, 従来の精緻化研究では付加すべき情報の 質を明らかにすることに主たる関心があり，そこでは 実験者が被験者に対して様久な精緻化情報を呈示する という操作が用いられてきた。しかし，その場合にも 被験者自身が自発的に精緻化している可能性は高いと 考えられる。それ故，被験者自身に精緻化させた場合 の記銘語の記憶に対する精緻化の有効性を検討するこ とは大切であろう。

Pressley, McDaniel, Ternure, Wood, \& Ahmad （1987）は,被験者自身が精緻化情報を生成する条件(生 成群) と, 実験者がその情報を呈示する条件(呈示群)で の記憶成績を比較している。例えば，記銘語 (hungry) を含む文 “The hungry man got into his car”に対して， 生成群では記銘語を含む文の下に“Why did that particular man do that?”という質問が示され，被験者が
自分で質問に対する答を考え，それを報告する。一方， 呈示群ではその文の後に“to go to the restaurant”とい う質問に対する答に対応する文があらかじめ実験者に よって示されていた。 その結果, 生成群の方が呈示群 より記銘語の偶発記憶成績が良かった. Slamecka \& Graf(1978) 以降, 同じ情報であっても, それを被験者自 身が生成する場合が，それを単に読ませる場合よりも 記憶成績が良いという現象は生成効果 (generation effect) と呼ばれているが, Pressley らの研究は記銘語に 対して情報を生成させることによって，生成の際に呈 示されていた記銘語の再生が促進されたのである.

本研究でも，同時に呈示される 3 つ記銘語から共 通に連想される語(関係情報)を生成させる生成群, 及

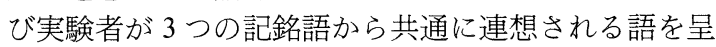
示する呈示群を比較し, 生成による再生の促進効果を 検討した.ただし, Pressley らの研究に限らず従来の精 緻化研究に対しては, 記銘語に対して確かに情報が付 加されたという指標すなわち精緻化の指標がないとい う批判(Baddeley, 1978)があった。そこで, 本研究では, 精緻化に関する次の 3 つの指標を設けることにした。 第 1 は, 関係情報の再生率であり，これを項目間精緻 化の指標とした。ただし，生成群での関係情報は $3 つ$ の記銘語から被験者自身が生成した語であり, 呈示群 では実験者によってあらかじめ記銘語と対呈示された 語となる。また，関係情報が符号化されてもそれによ 
って必ずしも一様に記銘語間のまとまりが形成される わけではない。この記銘語間のまとまりの程度は項目 間精緻化の有効性の程度を示すものである。そこで， 第 2 に, 項目間精緻化の有効性の指標として, 再生さ れた記銘語の群化量 $(\mathrm{PR}$, Moely, Olsen, Halves, \& Flavell, 1969)を算出した。第 3 は, 項目内精緻化の有 効性の指標である. 先に述べた Hunt らは, 検索過程が 記銘語のまとまりを検索する(産出) 過程と, このまと まりの中から呈示された記銘語であったか否かの区別 をする(弁別) 過程から成っており, 関係情報は産出過 程に機能し, 項目特殊情報は弁別過程に機能すると主 張している。それ故, 上記の産出過程においてまとま りの検索がなされた後の記銘語の検索は, 項目特殊情 報の符号化すなわち項目内精緻化の有効性に依存して いるといえよう。この有効性は, 関係情報が検索され た場合にその関係情報によって形成されたまとまり内 の個々の記銘語を検索できる確率に対応するものであ る。そこで，関係情報が再生された場合の記銘語の再 生率を項目内精緻化の有效性の指標とした。

したがって, 本研究の目的は, Pressley らと同じく生 成による促進効果が生じるならば，それが何を反映し たものなのかを上述した 3 つ指標によって検討する ことである。なお，本研究では 3 つの記銘語間の関連 性の有無という要因についても検討した. というのは, 記銘語間に関連のある場合には項目間精緻化が生じや すく，その有効性も高くなると考えられ，そのことが 促進効果の出現に影響するか否かは Pressley らの研究 でも検討されていなかったからである。

\section{方法}

実験計画 2 (群: 生成, 呈示) $\times 2$ (記銘語間の関連： 有, 無) の要因計画であり, 前者を被験者間要因, 後者 を被験者内要因とした。

被験者 被験者は大学生 71 名であり, 生成群には 38 名(男 13, 女 25), 呈示群には 33 名 (男 6, 女 27) が 割りあてられた。平均年齢は, 20 歳 6 力月 (19 歳 2 力 月一23歳 4 力月)であった。

材料 記銘語及び記銘語からの連想語の例が Table 1 に示されている。これらの語は梅本 (1969)の連想基 準表から選ばれた 1 -3 文字からなるよく知られた語 であった，本実験は，偶発記憶手続きを用いるので方 向づけ課題を行うが，そのためのリストが 2 種類用意 された。生成群用のリストは, 共通の連想語を持つ, 関連する 3 つの記銘語の組(トリプレット)が 5 トリプ レットと共通の連想語を持たない関連なしのトリプレ ットが $5 つ$ ，ランダムに配列されたものであった。こ れらのリストはB6判の小冊子にされたが，その小冊 子の各ページの上部に，3つの記銘語(トリプレット)
Table 1

The examples of targets and a paired-presented word in the present study

\begin{tabular}{ll}
\hline $\begin{array}{c}\text { 記銘語 } \\
\text { (targets) }\end{array}$ & $\begin{array}{c}\text { 対呈示語 } \\
\text { (paired-word) }\end{array}$ \\
\hline 赤い $\quad($ red $)$ & \\
あざみ & (thistle) \\
植物 $\quad$ (plant) & 花 (flower)
\end{tabular}

が印刷され，その下にその記銘語から連想される語を 書く空欄(『』)が記銘語よりやや小さく示され，さら にその下に連想の強さの程度に関する 5 段階評定尺度 が印刷された。

呈示群用のリストは，生成群用リストと，トリプレ ットの配列の順序は同じにされた。関連有トリプレッ トが印刷されたページでは，その下にトリプレットの 各語から共通に連想される語が，関連無トリプレット のページでは,トリプレットを構成する記銘語から共 通に連想されない語が対呈示語として, 記銘語よりや や小さく印刷されていた。なお，どちらのリストも初 頭, 新近位置効果を除くためにリストの最初と最後に バッファートリプレットが付け加えられ, 表紙をつけ た合計 12 ページの小冊子にされた。

自由再生テスト用紙は, B5 判の大きさで, 上部に氏 名を記入する欄が設けてあり，その下に思いだした語 (記銘語, 連想語の両方)を思いだした順に筆答するよ うになっていた。また，方向づけ課題と自由再生テス トの間に挿入課題を行うが，そのための用紙も用意さ れた。これはB4 判の大きさで, ひらがなの有意味な文 字列及び無意味な文字列で印刷されているものであっ た。

手続 実験は, 被験者の所属する学校の一室で集団 的に実施された。a)方向づけ課題 両群の被験者に上 述の小冊子を配布し, 生成群には小冊子の各ページの 上部に大きく印刷された 3 つ言葉から連想される言 葉を書くように指示した。また, 呈示群には, 3 つの言 葉から下に印刷された語がどの程度強く連想されるか を評定するように求められた. 雨群ともに, 1 ページに つき 10 秒が割り当てられ, 実験者の合図にしたがつ て, 生成群は共通連想語を記入し, 呈示群は評定を行 つていった。 b) 挿入課題 上述の用紙を配布し， 3 分 間の挿入課題を行った.この課題は, 3 文字以上のひら がなで構成される名詞をみつけて丸印をつけるもので あった。c)自由再生テス卜挿入課題終了後, 上述し た自由再生テスト用紙を配布し，筆答による自由再生 テストを 5 分間実施した。この際, 被験者には先に呈 示された小冊子に印刷された記銘語及び対呈示語を思 いつくだけ，思い出した順に書くように教示された。 
Table 2

Mean proportion of targets recalled, mean proportion of relational information recalled (between-item elaboration), mean clustering scores, and mean conditional probability of recalling targets given relational information (within-item elaboration) as a function of types of triplet and groups

\begin{tabular}{|c|c|c|c|c|c|c|c|c|}
\hline \multirow[b]{2}{*}{ groups } & \multicolumn{4}{|c|}{ related } & \multicolumn{4}{|c|}{ unrelated } \\
\hline & recall & $\begin{array}{l}\text { between-item } \\
\text { elaboration }\end{array}$ & clustering & $\begin{array}{l}\text { within-item } \\
\text { elaboration }\end{array}$ & recall & $\begin{array}{l}\text { between-item } \\
\text { elaboration }\end{array}$ & clustering & $\begin{array}{l}\text { within-item } \\
\text { elaboration }\end{array}$ \\
\hline $\begin{array}{l}\text { Subject- } \\
\text { generated }\end{array}$ & .35 & .51 & .76 & .51 & .24 & .32 & .37 & .38 \\
\hline $\begin{array}{c}\text { Experimenter- } \\
\text { provided }\end{array}$ & .47 & .72 & .64 & .59 & .15 & .42 & .27 & .21 \\
\hline
\end{tabular}

\section{結 果}

実験後，記銘の意図をもった者に挙手を求めたが挙 手はなく,全員が記憶意図を持たないことが示された。

正再生率 Table 2 の第 1 列には, 両群における平均 正再生率が示されている。この值を角変換して, 分散 分析を行ったところ, 関連の有無の主効果 $\left(F_{(1,69)}=\right.$ $88.48, p<.01)$ 及び群 $\times$ 関連の有無の交互作用 $\left(F_{(1,69)}=20.56, \quad p<.01\right)$ が有意であった。この交互作 用について，下位検定を行ったところ，関連有条件に おいて呈示群が生成群よりも正再生率が高く $\left(t_{(138)}=\right.$ $2.73, p<.01)$, 関連無条件に扔いては生成群が呈示群 よりも正再生率が高かった $\left(\left(t_{(138)}=2.82, p<.01\right)\right.$.

関係情報の再生率(項目間精緻化の指標) Table 2 の第 2 列には, 両群に扔ける関係情報(生成群では生成 語, 呈示群では呈示語)の再生率が示されている。この 值を角変換して分散分析を行った結果, 群の主効果 $\left(F_{(1,69)}=13.01, p<.01\right)$ 及び関連の有無の主効果 $\left(F_{(1,69)}=52.25, p<.01\right)$ が有意であり, 呈示群が生成群 よりも, 関連有条件が無条件よりも関係情報の再生率 が高かった。

群化量(項目間精緻化の有効性の指標) Table 2 の 第 3 列には, 平均群化量 $(\mathrm{PR})$ が示されている。これを 角変換して分散分析を行ったところ, 関連の有無の主 効果 $\left(F_{(1,69)}=43.46, p<.001\right)$ のみが有意であり, 関連有 条件が無条件よりも群化量の多いことが示された。

関係情報を再生した場合の記銘語の再生率(項目内 精緻化の有効性の指標) 生成群では生成語, 呈示群に おいては対呈示語を再生した場合の記銘語の再生率を 算出した。すなわち, 項目間精緻化が確かに生じてい る記銘語についてのみ再生率を算出したのである。そ の結果が Table 2 の第 4 列に示されている。これを角 変換して分散分析を行ったところ, 関連の有無の主効 果 $\left(F_{(1,69)}=45.59, p<.001\right)$ 及び群 $\times$ 関連の有無の交互 作用 $\left(F_{(1,69)}=9.88, p<.001\right)$ が有意であった. 交互作用
について下位検定を行ったところ，関連有条件では両 群間に差がないが $\left(t_{(138)}=1.16\right)$, 関連無条件では, 生成 群が呈示群よりもそれが高かった $\left(t_{(138)}=2.61, p<\right.$ .01).

\section{考察}

関連有条件では生成による促進効果は見られず，関 連無条件でのみその効果が認められた。 Pressleyらの 研究は，記銘語間に関連の無い条件で促進効果を見出 しており，本研究の結果は彼らの結果と一致するもの である。

さて, 本研究の目的は上記の促進効果が何によって 生じたものなのかを検討することであった。促進効果 の生じた関連無条件をみると, 項目間精緻化及びその 有効性の指標である群化量には群間に差がなく, 項目 内精緻化の有効性の指標においてのみ差があり, 正再 生率との対応関係が認められた。本実験では自由再生 事態の促進効果を検討したが, 検索過程としては Hunt らの主張する産出と弁別の両方の過程を含むので, 項 目間精緻化によってまとまりが検索されても, 項目内 精緻化が生じなければ個々の項目の弁別がなされな い. それ故, 関連無条件において促進効果が認められ たのは, 項目内精緻化の効果が反映されたものとみる ことができる. Anderson(1983) は, 多くの概念が連想 的な結合によって結び付いた認知構造を考え, 概念間 の活性化拡散 (spreading activation)を仮定している が，記銘語が呈示されると認知構造内の記銘語に対応 する概念領域が活性化する。そして，その記銘語と関 連ある記銘語が連続的に呈示されるとそれらの記銘語 に対応する隣接した概念の領域の活性化水準が急速に 高まり，その活性化が共通連想語に対応する概念だけ でなく, それ以外の連想語に対応する概念にまで拡散 すると述べている. 生成群においては共通連想語を生 成させたが，活性化の拡散により個々の記銘語独自の 連想語すなわち項目特殊情報が活性化され, それが項 
目内精緻化につながったのであろう。ただし, 関連無 条件では扔互いに関連の無い語であるので，3つの語 のうちのいずれか 1 語から語が生成される可能性もあ る。その場合には特定の記銘語と生成語との結びつき が強くなり，生成語が検索されれば，それを手がかり としてその記銘語も検索されるということも考えられ よう.

ところで, Pressley らは, 生成語の方が呈示語よりも 被験者の知識構造への適合の程度が高いことによって 促進効果の生じる可能性を述べている。知識構造への 適合性が高いということは, 記銘語と生成語の結びつ きが強いということである。したがって，生成語が再 生されれば，記銘語も再生される可能性が高いことに なる。それ故, Hunt らの主張とともに, Pressley らの 主張する被験者の知識構造との適合性の程度が呈示語 よりも生成語において大きいことを反映したという解 釈も可能である。しかし, Stein, Morris, \& Bransford （1978）では，記銘語に関連のある情報を付加すること が項目内精緻化の有効性を高めることが示されてい る.したがって, Pressleyらと Stein らの主張を併せて 考えると, 生成群では知識構造により適合するような 記銘語との関連性の高い情報を付加することによって 項目内精緻化の有効性が高まり, 促進効果が生じたと いえよう。

一方，関連有条件に扔いては，生成による促進効果 と逆の結果になった。関連有条件では呈示群が生成群 よりも関係情報の再生率(項目間精緻化の指標)が高か ったので，この項目間精緻化の違いが結果に反映して いると考えられる。ただし，関連無条件に扔いても呈 示群が生成群よりも関係情報の再生率は高く, 項目間 精緻化が再生率に反映しているならば, 関連無条件で も関連有条件と同じ結果になるはずである。しかし， 関係情報の再生率と記銘語の正再生率の相関係数 $(r)$ を算出してみると, 関連有条件では生成群が.42, 呈示 群が . 59 , 関連無条件では生成群が . 26 , 呈示群が .41 であり，関連有条件が無条件よりも項目間精緻化と正 再生率との関係の強いことがわかる。したがって，関 連有条件は関連無条件よりも項目間精緻化の違いが結 果に反映されやすい条件であるといえよう。さらに， 交互作用は有意ではないものの関連有条件における生 成群と呈示群の差 (.21) は関連無条件における差 $(.10)$ よりも大きくなっている。攵机故，関係情報と記銘語 の関係の強い関連有条件ではこの差が反映され,一方, この関係の強くない関連無条件では，この差は結果に 反映されにくいものと考えてよいであろう.
すなわち，関連有条件では，記銘語に対する連想語 が生成されたり, 対呈示されたりするのであるから, 記銘語と関係情報の間の結びつきが強いと考元られ る。それ故，関係情報が検索されれば，これが手がか りになって，対応する記銘語が検索される確率は高い といえよう。一方，関連無条件では，記銘語と関係情 報の結びつきは弱く, その結果として, 関係情報が検 索されても，これを手がかりとして対応する記銘語を 検索するのは困難であったと考えられる。したがって, 関係情報と記銘語間の結びつきの強さの程度が結果に 反映されたといえよう。

\section{引用文献}

Anderson, J. R. 1983 A spreading activation theory of memory. Journal of Verbal Learning \& Verbal Behavior, 22, 261-295.

Baddeley, A. D. 1978 The troubles with levels: a re-examination of Craik and Lockhart's framework for memory research. Psychological Review, 85, 139 -152 .

Hunt, R.R., \& Einstein, G.O. 1981 Relational and item-specific information in memory. Journal of Verbal Learning \& Verbal Behavior, 20, 497-514.

Hunt, R.R., \& Elliott, J.M. 1980 The role of nonsemantic information in memory: Orthographic distinctiveness effects on retention. Journal of Experimental Psychology: General, 109, 49-74.

Moely, B. E., Olsen, F. A., Halves, T. G., \& Flavell, J. H. 1969 Production deficiency in young children's clustered recall. Developmental Psychology, 1, 26-34.

Pressley, M., McDaniel, M. A., Turnure, J. E., \& Ahmad, M. 1987 Generation and precision of elaboration: Effect on intentional and incidental learning. Journal of Experimental Psychology: Learning, Memory \& Cognition, 13, 291-300.

Slamecka, N. J., \& Graf, P. 1978 The generation effect: Delineation of a phenomenon. Journal of Experimental Psychology: Human Learning \& Memory, 4, 592-604.

Stein, B.S., Morris, C.D., \& Bransford, J.D. 1978 Constraints on effective elaboration. Journal of Verbal Learning \& Verbal Behavior, 17, 707-714.

豊田弘司 1987 記憶に扔ける精緻化(elaboration) 研 究の展望 心理学評論, 30, 402-422.

梅本堯夫 1969 連想基準表 東京大学出版会

—1991.8.5.受稿, 1993.1.23.受理—— 